\title{
Insecticidal Activity of Castanospermum australe against stored Grain Pest Callosobruchus analis
}

\author{
Zafar Alam Mahmood ${ }^{1}$, Salman Ahmed ${ }^{2}$, Syed Waseemuddin Ahmed ${ }^{3}$, Muhammad \\ Mohtasheem ul Hasan ${ }^{4 *}$ \\ ${ }^{1}$ (Department of Pharmaceutics, Faculty of Pharmacy, University of Karachi, Karachi -75270, Pakistan) \\ ${ }^{2-4}$ (Department of Pharmacognosy, Faculty of Pharmacy, University of Karachi, Karachi-75270, Pakistan)
}

\begin{abstract}
The butanol fraction of the leaves of Castanospermum australe Cunn. \& Fraser., was tested on adult Callosobruchus analis (pulse beetle) for its insecticidal activity by impregnation method at concentration of 3, 9, 48, 240 and $354 \mu \mathrm{g} / \mathrm{cm}^{2}$. The result showed that the extract is toxic to Callosobruchus analis and the $\mathrm{LD}_{50}$ was found to be $38 \mu \mathrm{g} / \mathrm{cm}^{2}$.
\end{abstract}

Keywords-Callosobruchus analis, Castanospermum australe, Grain pest, Insecticidal activity, Saponins.

\section{INTRODUCTION}

Insect pest management is world widely facing the economic and ecological challenges due to the uses of the synthetic pesticide chemicals. Plants containing active insecticidal phytochemicals are gaining a lot of attention because of having broad-spectrum insecticidal activity, safety, biodegradability and integrated crop management approaches. In addition, globally they are playing a vital role in organic food production. Therefore, phytochemicals can be used in insecticide design with specific or multiple target sites, as well as serve as model compound for the development of chemically synthesized derivatives with enhanced activity. Increasing number of researchers have described the active insecticidal phytochemicals that play an effective role in sustainable pest management [1-6].

Castanospermum australe Cunn. \& Fraser., (Family, Papilionaceae) is cultivated as an ornamental tree on the roadside in Pakistan [7]. In traditional medicine, the pods of the plant are reported as astringent [8] and In treatment of post pyrandial hyperglycemia in diabetic patients [9]. On literature survey it was found that the wood of Castanospermum australe contains castanogenin and bayogenin [10] whereas castanogenol from bark [11], castanospermine [12] and australine [13] from seed are reported. Saponins from the fresh leaves of Castanospermum australe have also been characterized [14,15].

The present work was undertaken in view of the fact that the leaves of Castanospermum australe in particular produce saponins. Since no work on insecticidal activity has apparently been carried out on the saponins constituents of leaves, therefore, the butanol fraction of the leaves of Castanospermum australe was investigated for insecticidal activity against an important pest of pulses, Callosobruchus analis.

\section{MATERIALS AND METHODS}

2.1. Plant material: The leaves of Castanospermum australe Cunn. \& Fraser was collected from Karachi in the month of April and specimen was kept in Department of Pharmacognosy for future reference.

2.2. Extraction: The fresh leaves $2 \mathrm{~kg}$ of the plant were soaked in $\mathrm{EtOH}$ and kept at room temperature for one week. The ethanolic extract was evaporated under reduce pressure. The dark green material $45 \mathrm{~g}$ so obtained was suspended in water the fractionated with hexane and thereafter with ethylacetate, the aqueous fraction was shaken vigorously with saturated $\mathrm{n}-\mathrm{BuOH}$. The $\mathrm{n}-\mathrm{BuOH}$ layer was evaporated under high vacuum, $14 \mathrm{~g}$ of the crude butanol fraction was obtained.

2.3. Insecticidal activity: All the insects were obtained from a colony of Callosobruchus analis reared in the laboratory under controlled condition $\left(28^{\circ} \mathrm{C}\right.$ and $60 \%$ humidity), so that the insects of uniform size and age were available. The insects were reared in glass jars and the mouths of jars were covered with muslin cloth, tied by means of rubber bands. Grains of Vigna mungo (L.) Hepper (Vern. Mash) were used as food and breeding media. After emergence the new insects were transferred into fresh grains. 
2.4. Preparation of samples: A 5\% stock solution of the butanol fraction was prepared in distilled water. Different concentrations such as $0.01,0.04,0.2,1.0$ and $1.5 \%$ were prepared, and then converted into dose as $\mu \mathrm{g} / \mathrm{cm}^{2}$ which was 3 $, 9,48,240$ and $354 \mu \mathrm{g} / \mathrm{cm}^{2}$ respectively.

2.5. Method of treatment: Different concentrations of butanol fraction were applied on filter paper by impregnation method [16]. With the help of pipette, $1.5 \mathrm{ml}$ of each dilution were applied on the filter paper and kept in petri dishes $(9 \mathrm{~cm} \mathrm{dia)}$, whereas $1.5 \mathrm{ml}$ of distilled water was used in the control samples. Twenty adult insects were released in each petri dish. After 24 hours, mortality of Callosobruchus analis was noted in each petri dish. Each experiment was repeated five times. The average percent mortality is given in Table.

\section{RESULTS AND DISCUSSION}

The insecticidal activity of the butanol fraction of Castanospermum australe leaves against adult Callosobruchus analis was determined by impregnation method in five different concentrations and the result so obtained revealed that the extract is toxic against the test insect (pulse beetle). The mortality was lowest (14\%) at $3 \mu \mathrm{g} / \mathrm{cm}^{2}$ and highest (96\%) at 354 $\mu \mathrm{g} / \mathrm{cm}^{2}$ (Table). The $\mathrm{LD}_{50}$ by log-log graph was found to be $38 \mu \mathrm{g} / \mathrm{cm}^{2}$.

Table: Insecticidal activity of Castanospermum australe (butanol fraction) against Callosobruchus analis.

\begin{tabular}{|l|l|l|}
\hline $\begin{array}{l}\text { Dose } \\
\boldsymbol{\mu g} / \mathbf{c m}^{\mathbf{2}}\end{array}$ & $\begin{array}{l}\text { Percentage } \\
(\boldsymbol{\%}) \\
\text { Mortality }\end{array}$ & $\mathbf{\pm S D}$ \\
\hline 3 & 14 & 02.72 \\
\hline 9 & 26 & 03.50 \\
\hline 48 & 64 & 03.46 \\
\hline 240 & 86 & 04.17 \\
\hline 354 & 96 & 03.16 \\
\hline$n=5$
\end{tabular}

The multiple mechanisms of action give phytochemicals unique properties that make it very useful in today's agricultural industry e.g. azadirachtin from Melia azadirachta L. [17]. The plants secondary metabolites act as a defender against microbial pathogens and invertebrate pests [18]. The saponins are highly toxic when given intravenously to higher animals but their toxic effects are very much lower when they are administered orally [19] and many of the saponins of foods and feeding stuffs are apparently without any significant oral toxicity. However the saponins of Castanospermum australe are orally toxic to adult grain pest Callosobruchus analis. Saponins have been utilized as molluscicidal activity should also be taken into consideration. Two species of Swartzia, S. madagascariensis Desv., and S. simplex Spreng., contained saponins consisting of glucoronides of oleanolic acid, gypsogenin and gypsogenic acid exhibited molluscicidal activity of the isolated compounds against schistosomiasis transmitting snails Biomphalaria glabrata [20,21]. The insecticidal activity of saponins is due to the interaction with cholesterol, disturbance in ecdysteroid synthesis, protease inhibition or cytotoxicity of insects [22]. Similarly saponins of Castanospermum australe leaves also contains oleanane type of saponins as bayogenin, medicagenic acid and gypsogenic acid glycosides [14,15], therefore, chemical structure and activity relationship has demonstrated lethal activity saponins against Callosobruchus analis .

\section{CONCLUSION}

It may be said that the saponins of this plant could be utilized as a natural insecticide that could be an effective alternative for insect pest management.

\section{REFERENCES}

1. M.F. Ryan, and O. Byrne, Plant-insect coevolution and inhibition of acetylcholineesterase, .Journal of Chemical Ecology, 14(10), 1988, 1965-1975.

2. J.T. Arnanson, S. Mackinnon, M.B. Isman and T. Durst, Insecticides in tropical plants with nonneurotoxic modes of action, Recent Advances In Phytochemistry., 28,1992, 107-131.

3. D.J. Chitwood, Phytochemical based strategies for nematode control, Annual review of phytopathology, 40, 2002, 221-249. 
4. I.K..Park, J.Y.Park., K.H. Kim., K.S. Choi., I.H. Choi, C.S. Kim and S.C.Shin, Nematicidal activity of plant essential oils and components from garlic (Allium sativum) and cinnamon (Cinnamomum verum) oils against the pine wood nematode (Bursaphelenchus xylophilus), Nematology, 7(5), 2005, 767-774.

5. M.B. Isman, Botanical insecticides, deterrents and repellents in modern agricultural and an increasingly regulated world, Annual Review of Entomology, 51, 2006, 45-66.

6. R. S. Rattan, Mechanism of action of insecticidal secondary metabolites of plant origin, Crop Protection, 29(9), 2010, 913-920.

7. S.I.Ali, Flora of Pakistan (Nasir, E., Ali, S. I., Eds.). Papilionaceae, (Karachi: Fakhri Printing Press, 1977) 30.

8. R.N.Chopra, S.L. Nayar and I.C. Chopra, Glossary of Indian Medicinal Plants, (New Delhi: Council of Scientific and Industrial Research, 1956) 55.

9. R.J. Nash, S.V. Evans., L.E. Fellows and E.A. Bell, In: Plant Toxicolgy, A. A. Seawright, M. P. Hegarty, L. F. James and R. F. Keeler (Eds.) (Melbourne:Dominion Press Hedges and Bell, 1985) 309-314.

10. R.A. Eade, J.J.H., Simes and B. Stevensen, Extraction of Australian timers, IV Castanogenin (Medicagenic acid) and Bayogenin, $\mathrm{C}_{30} \mathrm{H}_{48} \mathrm{O}_{5}$, from Castanospermum australe Cunn et Fras, Australian Journal of Chemistry, 16(5), 1963, 900-905.

11. M.G. Rao, L.R., Row and C. Rukmini, Chemistry of saponins Part IV, A new triterpene sapogenin, Castenogenol from the bark of Castanospermum australe Cunn. Fras, Indian Journal of Chemistry, 7(12), 1969, 1203-1205.

12. L.D. Hohenchutz, E.A. Bell., P.J. Jewess., D.P. Leworthy., R.J. Pryce., E. Arnold and J. Clardy, Castanospermine, A 1,6,7,8-tetrahydroxyoctahydroindolizine alkaloid, from seeds of Castanospermum australe, Phytochemistry, 20(4), 1981, 811-814.

13. R.J. Molyneux, M. Benson., R.Y.Wong., J.E. Tropea and A.D. Elbein, Australine, A novel pyrolizidine alkaloid glucosidase inhibitor from Castanospermum australe, Journal of Natural Products, 51(6), 1988,1198- 1206.

14. V.U. Ahmed, W. Ahmed and K. Usmanghani, Triterpenoid saponins from leaves of Castanospermum australe, Phytochemistry, 31(8), 1992, 2805-2807.

15. W. Ahmed, U.G. Khan., I. Ahmed., V.U. Ahmed and T. Miyase. Isolation and characterization of saponins from Castanospermum australe Cunn. et Fraser, Chemical \& Pharmaceutical Bulletin(Tokyo), 42(2), 1994, 314-317.

16. S.N.H.Naqvi, R . Tabassum., N .Zia and S.M. Nurulain, Toxicity and residual effect of Neem extract (Factor C) against stored grain pest Callosobruchus analis, Pakistan Journal of Zoology, 22(3), 1990, 271-277.

17. L.G. Copping, and J.J. Menn, Biopesticides: a review of their action, applications and efficacy, Pest Management Science, 56(8), 2000, 651-676.

18. O.R. Gottlieb, Phytochemicals: differentiation and function, Phytochemistry, 29 (6), 1990, 1715-1724.

19. A.J. George, Legal status and toxicity of saponins, Food and Cosmetics Toxicology, 3, 1965, 85-91.

20. C. Borel, and K . Hostettman, Molluscicidal saponins from Swartzia madagascariensis, Helvetica Chimica Acta, 70(3), 1987, 570-576.

21. C. Borel, M.P. Gupta and K . Hostettman, Molluscicidal saponins from Swartzia simplex, Phytochemistry, 26(10), 1987, 2685-2689.

22. I.Chaieb, Saponins as Insecticides: a Review, Tunisian Journal of Plant Protection, 5(1), 2010, 39-50. 